EL'̇BIETA AWRAMIUK'

DOI: $10.15290 / C R .2020 .30 .3 .02$

University of Białystok

ORCID: 0000-0003-1769-7265

MICHAŁ CITKO 2

University of Białystok

ORCID: 0000-0002-8136-8354

\title{
Unseized opportunity. Respelling of English words in L1 Polish textbooks
}

\begin{abstract}
The purpose of this study is to present the results of an analysis of several Polish textbooks, popular in primary schools (grades 4-6, age 10-13), to demonstrate how Polish textbooks give the pronunciation of English words. Authors of textbooks use their native orthographic convention for sound form signalization called respelling. It is a simple and convenient strategy for indicating pronunciation more accurately than normal spelling. However, respelling of English words poses some problems related to the use of L1 alphabet for decoding foreign language sounds, such as domestication or omitting relevant phonetic information. Another problem concerns the indistinct separation of the two forms of language - written and spoken - due to the use of letters for signalling sound form. L1 classes create a perfect opportunity for students to develop their linguistic awareness. This opportunity, however, does not seem to be fully embraced by the authors of the textbooks. Generally, there is a lack of wellthought-out solutions aimed at the orthoepic competence concerning phonetic transcription conventions. Thus, some ways of clarification of how the sounds of spoken language are represented in written form are proposed.
\end{abstract}

Keywords: primary school, textbook analysis, sound form signalization, respelling, linguistic awareness.

\section{Introduction}

The awareness of basic differences between languages (e.g. concerning pronunciation, spelling or grammar) is an important factor of linguistic competence (cf. CEFR: 4-5). Within school education, the development of this awareness should not be restricted

1 Address for correspondence: Faculty of Philology, University of Białystok, Plac Uniwersytecki 1, 15-420 Białystok, Poland. E-mail: e. awramiuk@uwb.edu.pl

2 Address for correspondence: Faculty of Philology, University of Białystok, Plac Uniwersytecki 1, 15-420 Białystok, Poland. E-mail: m.b.citko@gmail.com 
to foreign language classes only but should be shaped whenever there is an opportunity for it. One such opportunity is the presence of foreign words in an L1 class where the pronunciation of foreign words in textbooks is provided more often than the pronunciation of Polish words (Awramiuk 2018). Also, the introduction of comparative elements is a chance to increase students' awareness of their mother tongue as well as to develop their metalinguistic knowledge.

The purpose of this study is to present the results of an analysis of six Polish textbooks to demonstrate the strategies of giving the pronunciation of English words and see whether they can be used to increase students' knowledge of the languages and general linguistic awareness. First, some remarks about the ways of representing sounds in the written form will be presented and some basic terms will be explained. Then the focus will shift onto the phonemic awareness in education as well as phonetics in Polish curricula. In the next section, the methodological clarifications outlined. The main body of the paper presents the results of the analysis of two popular series of Polish L1 textbooks from the second cycle of elementary school. This part contains general remarks about the scope and conventions of respelling, as well as issues concerning the respelling of English words. In the discussion, three problems will be outlined.

\section{Theoretical background}

\subsection{Phonetic representation of sounds}

The problem of clarification of how the sounds used in spoken language are represented in written form is important from the point of view of language education. There are many ways to represent sounds using written symbols (Heselwood 2013) which is connected with different purposes and priorities. First of all, the main distinction between phonetic transcription and other ways of sound form signalization (SFS) should be explained.

Phonetic transcription is a notation system used in specialized sources. It comprises a set of special symbols linked to the theory by interpretative conventions (Heselwood 2013: 25) such as those of the International Phonetic Alphabet (IPA) or the Slavonic Phonetic Alphabet (SPA). Various systems of transcription are based on these alphabets. However, it is important that - no matter what type of transcription is used (specific or generic, broad or narrow, etc.) - phonetic transcription has established rules. Other methods of sound form signalization (SFS) are used in non-specialist sources (e.g. in language teaching materials, in monolingual and bilingual dictionaries) and they are less conventionalized. One of them is respelling which uses orthographic conventions but regularizes their correspondences with sound so that, as far as possible, the same character corresponds to the same pronunciation element (Heselwood 2013: 28). Respelling is a strategy for indicating pronunciation more accurately than normal 
spelling. The Polish word krzak in the IPA is written [kfak] and in the SPA - [kšak], which requires knowledge of the phonetic value of the new graphic symbol: $\int$ or $\check{s}$, while the form of the respelled word [kszak] is closer to the orthographic representation and its reading requires only the knowledge of the letters of the Polish alphabet.

Respelling is used in different sorts of publications which are aimed at users who are assumed to have no specialist knowledge of phonetics. Usually, it helps them with the pronunciation of single words. This type of SFS is, for instance, used in the monolingual Polish orthoepic dictionary Nowy słownik poprawnej polszczyzny (NSPP), as well as in teaching English as a foreign language in Poland (Furtak 2015). Respelling is much less standardised than the IPA or the SPA and there is more variation between practitioners, but this method of SFS is adequate for users who are not familiar with more specialistic phonetic scripts. Respelling is also used by those who want to transcribe the heard pronunciation of unknown words, e.g. in foreign language learning.

\subsection{Phonemic awareness in L1 and L2 education}

Linguistic awareness is an important part of language education and phonemic awareness is one of its elements. Phonetics has a primarily utilitarian value in education. The purpose of phonetic exercises in foreign language classes is to achieve appropriate phonological (the knowledge and skill related to the perception and production of the phonemes) and orthoepic competence concerning, among others, the knowledge of conventions used for the representation of pronunciation (CEFR: 117-118).

For obvious reasons, it is different in learning a native language. A school child can easily differentiate and manipulate native phonemes. However, phonemic awareness plays a crucial role in learning reading and writing languages with an alphabetic script, like Polish or English. In fact, phonological awareness and the knowledge of letters are considered the main factors influencing literacy in those languages (National Early Literacy Panel 2008). At later stages, phonetics serves to understand cultural texts better, and at all educational stages, it supports speaking. Phonetics understood as a reflection on speech sounds, the relationship between speech and writing, and speech in the suprasegmental level, is an important element in the development of language and communication competences.

The above mentioned practical aspects of phonetics constitute the functional dimension of phonetic instruction in school. Functional dimension means fostering language skills (e.g. spelling and reading aloud). The second dimension is normative, which means giving importance to correct pronunciation no matter whether this contributes to fostering language skills.

In Poland, language education in L1 and L2 is normally separated but language awareness - which is cross-disciplinary (Svalberg 2012: 377) - can be developed in school education also during mother tongue education. It is the opportunity to shape the awareness 
of the similarities and differences between the mother tongue and foreign languages. The benefits of such holistic education are appreciated in the Finnish educational system, where the National Core Curriculum emphasises the similarity of language education in the mother tongue and foreign languages. The Finish Curriculum considers the pupils' plurilingual competence, and it highlights the importance of communicative competence as well as language awareness (Nupponen et al. 2019).

\subsection{Phonetics in Polish curricula}

The provisions of the core curriculum for teaching Polish as a mother tongue in recent years (cf. CC 2008; CC 2014; CC 2017) encouraged the integration of the content of education (language, literature, culture and communication), functional language education and practical use of acquired information (Bartmiński 2009; Kowalikowa 2014; CC 017: $18,60,62,70)$. The conceptual network proposed in the core curricula is designed to build students' linguistic self-awareness and develop their language skills, improve linguistic correctness and teach in-depth reception of texts. Both dimensions (functional and normative) are present in the Polish curricula, although the first one seems to be more prominent. The purpose of language education is, among others, to develop the skills of correct speaking and writing in accordance with the principles of orthophony and Polish spelling (CC 2017: 59), as well as - in terms of formulating utterances - to improve the phonatory, articulatory and prosodic aspect of students' speech (CC 2017: 60).

In the 2017 core curriculum, the 2nd educational stage includes grades 4-6, but the provisions concern two age groups: grades 4-6 and grades 7-8. The detailed requirements concerning L1 language education for the first group include, among others, students' understanding of the terms: sound, letter, syllable, stress, the knowledge and ability to apply the rules for stressing words and correct intonation depending on the purpose of the utterance (CC 2017: 63).

When it comes to making utterances, the student should be able to deliver from memory a text with appropriate intonation, diction, stress, emotional tension and pausing, supporting himself or herself in that with relevant language knowledge (CC 2017: 64). The last provision can refer to, among others, the use of knowledge of the relationship between speech and writing (phonetic assimilation, assimilation of consonant groups and final devoicing) when mastering the correct Polish spelling (CC 2017: 67-68). Teaching phonetics in primary school is closely related to teaching spelling, which results from the fact that Polish spelling is largely morphophonological.

With respect to modern foreign languages, the core curriculum is common to all of them. In grades 1 to 6 of primary school, each student must learn one foreign language, and from grade 7 - two foreign languages. Different variants of the general education core curriculum (CC 2017: 20) result from the fact that different foreign languages can be 
taught to students of different grades and different levels of proficiency, but all have been developed with reference to the levels of proficiency pertaining to particular language skills specified in the Common European Framework of Reference for Languages (CEFR).

The core curriculum - in addition to the general provision on language awareness regarding similarities and differences between languages (CC 2017: 75) - does not suggest how the teaching of the mother tongue and modern foreign languages can be correlated. The teachers, however, recognize the mutual benefit from the interpenetration of foreign and native language content in lessons (Kietlińska \& Awramiuk 2016).

\section{Methodological remarks}

The next paragraph gives an overview of how English words are respelled in Polish L1 textbooks. Our consideration is the effect of an analysis of two series (each consisting of 3 textbooks) of Polish textbooks for the second stage of the primary schools (grades 4-6, age 10-12). The choice of this stage was dictated by the fact that it is considered the most natural for the functional teaching of grammar and therefore crucial for shaping language awareness.

The following textbooks were selected for the analysis: Między nami [Between us] (MN) and Teraz polski [Now Polish] (TP) ${ }^{3}$. The choice was determined by the fact that both series are one of the most popular textbook series in Poland ${ }^{4}$ and both integrate items of reading, language education, and literature, but this integration can be understood in different ways. The textbooks are in line with the Polish National Curriculum and have been formally accepted by the MEN (Ministry of Education).

The analysed textbooks were published in the years 2013-2018, so they were based on the core curriculum from 2008 (CC 2008), but it is worth emphasizing that the CC 2014 did not bring any changes in our area of interest. The latest CC introduced in 2017 - although it carries a significant reorganization of the education system - is still being implemented ${ }^{5}$. The differences in textbooks of the same series published in 2013-2016 and those published after 2017 are generally small and do not concern the analysed issues. In general, we believe that the identified problems are also valid in relation to new textbooks published on the basis of the latest curriculum.

\footnotetext{
3 References to specific books specify the grade, e.g. MN4 means the textbook Między nami, grade 4.

4 This is a statement based on our own observations, as well as on the observation of publishers' activity. However, it cannot be verified because publishers in Poland do not provide information about their publications.

5 In the school year 2018/2019, when the textbooks were being analysed, in relation to the implemented curricular reform in primary schools, the old (pre-reform) textbooks were used for grade 6 and new textbooks for grades 4, 5, 7 and 8 .
} 
The analysis of textbooks was conducted in the following steps. First, the analysis was focused on searching for places where orthographic representation changes to fulfil the needs of SFS. All foreign and Polish words with signalled pronunciation were written down and quantitatively analysed. At this stage, the aim was to analyse the distribution and frequency, as well as the conventions of respelling in the textbooks. Next, the respelled words identified in the analysed data were examined more thoroughly.

\section{Results}

\subsection{Sound form signalization in Polish L1 textbooks - general remarks}

There are four categories of words whose sound form is signalized in the analysed textbooks:

1. native words, e.g. "if there is a voiced sound at the end of the word, we pronounce it as a voiceless, for example sad, czyt. sat" (MN5: 346);

2. borrowings, e.g. lunch, czyt. lancz (MN6: 44);

3. foreign proper names, e.g. Joe, czyt. Dżoł (MN4: 343), Joe [czytaj: dżoł] (TP5: 120);

4. other foreign words and phrases from foreign languages, e.g. digital painting [didżital pejnting] (TP5: 299).

The differences between groups (2) and (4) should be explained. Borrowings are more recent words in the Polish language which have preserved their original spelling and have a high frequency in contemporary texts. "Other foreign words" are foreign lexical units which are not treated as borrowings but rather as code-switching. The distribution and frequency for the four groups of words in textbooks are resumed in Table 1.

Table 1. The distribution and frequency of respelled words in analysed textbooks (English words in parentheses)

\begin{tabular}{|c|c|c|c|c|c|c|c|c|}
\hline Categories of words & TP4 & TP5 & TP6 & $\begin{array}{c}\text { Total } \\
\text { TP }\end{array}$ & MN4 & MN5 & MN6 & $\begin{array}{c}\text { Total } \\
\text { MN }\end{array}$ \\
\hline native words & 0 & 2 & 0 & 2 & 0 & 43 & 0 & 43 \\
\hline borrowings & $\begin{array}{l}11 \\
(9)\end{array}$ & $\begin{array}{c}13 \\
(10)\end{array}$ & $\begin{array}{l}13 \\
(8)\end{array}$ & $\begin{array}{c}37 \\
(27) \\
\end{array}$ & $\begin{array}{c}6 \\
(5) \\
\end{array}$ & $\begin{array}{c}12 \\
(11)\end{array}$ & $\begin{array}{c}6 \\
(5) \\
\end{array}$ & $\begin{array}{c}24 \\
(21) \\
\end{array}$ \\
\hline foreign proper names & $\begin{array}{l}124 \\
(95)\end{array}$ & $\begin{array}{c}154 \\
(107)\end{array}$ & $\begin{array}{l}160 \\
(83)\end{array}$ & $\begin{array}{c}438 \\
(285)\end{array}$ & $\begin{array}{c}37 \\
(22) \\
\end{array}$ & $\begin{array}{c}51 \\
(25) \\
\end{array}$ & $\begin{array}{c}59 \\
(46)\end{array}$ & $\begin{array}{l}147 \\
(93)\end{array}$ \\
\hline other foreign words & 0 & $\begin{array}{c}4 \\
(2) \\
\end{array}$ & $\begin{array}{c}8 \\
(1)\end{array}$ & $\begin{array}{l}12 \\
\text { (3) }\end{array}$ & 0 & $\begin{array}{c}1 \\
(0)\end{array}$ & $\begin{array}{l}15 \\
(1)\end{array}$ & $\begin{array}{l}16 \\
(1)\end{array}$ \\
\hline Total & $\begin{array}{c}135 \\
(104)\end{array}$ & $\begin{array}{c}173 \\
(119)\end{array}$ & $\begin{array}{l}181 \\
(92)\end{array}$ & $\begin{array}{c}489 \\
(315)\end{array}$ & $\begin{array}{c}43 \\
(27)\end{array}$ & $\begin{array}{l}107 \\
(36)\end{array}$ & $\begin{array}{c}80 \\
(52)\end{array}$ & $\begin{array}{c}230 \\
(115)\end{array}$ \\
\hline
\end{tabular}


The quantitative analysis shows that SFS in the textbooks much more often concerns foreign words (674 in both textbooks) than native (45). Foreign proper names are definitely predominant. This group in TP series is related to the concept of literary and cultural education adopted in the textbooks. Culture is represented by a highly diverse international set of texts. All names of the authors and the titles of their works are transcribed. More native words with SFS in MN results from the fact that there is more focus on explicit grammar (or even explicit knowledge about language) in this series. English words (430) are clearly predominant, especially in the categories 2 and 3. They amount to $63.8 \%$ of all the foreign words.

SFS in the MN series appears on the margins of the textbook, and in the TP series linearly in the texts of readings. It performs a similar function in both series. The main purpose of SFS of foreign words is to provide an approximate pronunciation of the words usually used in text extracts. The pronunciation of the most dominant group of words foreign proper names - concerns the names of authors of text extracts, artists and their works, literary heroes, geographical locations, etc. In TP6 (p. 304) respelling was used in the main text of the textbook to signal the variance of the spelling of the latest borrowings in the Polish language. These words can be written preserving their original form (e.g. weekend) or according to the Polish pronunciation (e.g. dzinsy 'jeansy') or in both ways (e.g. aquapark or akwapark).

The sound form in both textbooks is signalized using respelling. Respelling is a simple and convenient strategy, but the way it is used in the analysed textbooks generates some difficulties which will be discussed in the next section. Meanwhile, it should be added that only the segmental speech features (sounds) are signalized in foreign words. The ways of respelling are presented in Table 2.

Table 2. Respelling conventions adopted in the textbooks

\begin{tabular}{|l|l|l|}
\hline \multicolumn{1}{|c|}{ Units } & \multicolumn{1}{|c|}{ MN } & \multicolumn{1}{|c|}{ TP } \\
\hline assimilated foreign words & spray - czyt. sprej (MN4: 216) & $\begin{array}{l}\text { musical [czytaj: mjuzikal] } \\
\text { (TP4: 29) }\end{array}$ \\
\hline foreign proper names & $\begin{array}{l}\text { Charles Schulz - czyt. Czarls } \\
\text { Szulc (MN4: 164) }\end{array}$ & $\begin{array}{l}\text { Orson Welles [czytaj: łels] } \\
\text { (TP5: 213) }\end{array}$ \\
\hline other foreign words & $\begin{array}{l}\text { send on a fool's errand - } \\
\text { czyt. send on a fuls erent } \\
\text { (MN6: 160) }\end{array}$ & $\begin{array}{l}\text { live scanner [czytaj: } \\
\text { lajf skaner] (TP5: 313) }\end{array}$ \\
\hline
\end{tabular}

Although the authors of both analysed textbooks use respelling, they do it in a slightly different way. In the Teraz polski series, the pronunciation is given in square brackets 
after the word czytaj 'read' with a colon. In Między nami, the pronunciation is signalled by the abbreviation czyt. (without square brackets), after which proper names are written with capital letters. This way of signalling pronunciation poorly separates writing and speech.

\subsection{Issues concerning the respelling of English words}

Sound form signalization in the analysed textbooks takes place through the native language alphabet, which is rather natural. It is difficult for a child who recently got to know the first set of written characters (an alphabet), to understand/learn another one (a phonetic alphabet). However, there is a whole list of problems that are connected with the application of respelling in the textbooks. The list includes incorrect, incomplete, inconsistent, domesticated and mixed transcription.

The first problem concerns incorrect sound identification of the respelled word, which results or may result in the wrong production. For example, the name Hobbes is rendered [czytaj: hobs] (TP5: 324, TP6: 82), which gives an unpronounceable cluster of a voiced and unvoiced consonant [bs] which in reality will be pronounced either as [bz] or [ps]. Another example is the word Rosemary [czytaj: rozmery] (TP5: 36), in which the vowel in the stressed syllable is given as a monophthong [o] instead of a diphthong [oł].

Another problem concerns the lack of stress marking in polysyllabic words in both coursebooks, e.g. Scott McVay [czytaj: skot makwej] (TP6: 73), DOGTV [czytaj: dog tiwi] (TP6: 83). If the adopted convention is going to help students reach at least an approximated sound form of the word then, they not only need segmental information (concerning individual sounds) but also suprasegmental (concerning stress). The lack of stress in many cases makes it impossible to reconstruct the correct sound form.

Inconsistency of transcription can appear at the level of words or sounds. At the word level, it is most easily observed on the example of frequently appearing names, e.g. Jack - czyt. Dżak (MN6: 246), czyt. Dżek (MN6: 70), Joe - czyt. [dżoł] (MN4: 343), [czytaj: dżoł] (TP5: 120, TP6: 341), [czytaj: dżo] (TP4: 154). Different versions can be observed even within one series.

Inconsistent transcription can also concern the level of sounds, i.e. the same sound can be rendered differently in different words. For example, the sound [n] (velar nasal), which is present in Polish but appears in a different phonetic context than in English, can be rendered as [n] in Lofting [czytaj: loftin] (TP5: 326) or [ng] in painting [czytaj: pejnting] (TP5: 299) (an unlikely pronunciation, considering the fact that Polish devoices final consonants).

However, this type of inconsistency also occurs when there is no unambiguous equivalent of a L2 sound in the L1 phonological system and hence - no suitable letter in the L1 alphabet. In this case, the same sound could have a different graphic representation in different words, e.g. English sound [ $[\Theta]$ (voiceless, fricative, dental) is represented by Polish sound [f] with a slightly different place of articulation (voiceless, fricative, 
labiodental) or [t] with a different manner of articulation (voiceless, plosive, alveolar) ${ }^{6}$, as illustrated by examples Ethan - czyt. Ifen (MN6: 58) and Elizabeth [czytaj: elizabet] (TP5: 37). This problem is not only one of consistency but also of domestication.

Respelling poses some problems related to the use of the mother tongue alphabet for decoding foreign-language sounds since it does not allow the transfer of those L2 phonological features that do not have a distinctive function in L1, as vowel length or diphthongs in Polish. This inevitably leads to domestication such as swapping sounds or omitting relevant phonetic information. Several categories pertaining to domestication-related problems can be distinguished for the respelled words in the analysed coursebooks ${ }^{7}$ :

- $\quad$ swapped diphthongs, e.g. Wilde [łajld] (MN6: 319), where the English diphthong [ar] is represented in Polish alphabet by two segments: a vowel [a] and a semi-vowel [j]; similarly [or] is swapped for [oj]: Roy [roj] (TP4: 183), [eI] for [ej]: Baker [bejker] (TP5: 76), [aI] for [aj]: Wright [rajt] (TP5: 148), [av] for [ał]: Downa [dałna] (TP6: 241), [əə] for [oł]: Ernshaw [ernszol] (TP6: 169);

- $\quad$ swapped consonants, e.g. Ethan [ifen] (MN6: 58), where an English consonant [ $\Theta$ ] (non-existent in Polish) is swapped for a Polish one [f];

- no vowel length distinction (long, short and reduced), e.g. fantasy [fantazy] (TP5: 123), where a short vowel (though perceptually relatively long) [æ] and a reduced (much shorter and less tense) vowel [ə] are represented by the same [a].

The last identified problem concerns mixing transcription and ortography which means an unconscious preference for the written form over the sound form. The word sherwoodzkich (a Polish derivate of the English word Sherwood) should be rendered [szerłuckich] in respelling because of the typical consonant assimilations in Polish but it was given as [szerłudzkich] (MN6: 230), which is closer to the orthographic form. A similar rendition (close to the orthography) was provided for the word hollywodzki czyt. holiłudzki (MN 5: 357). This approach to respelling could be confusing to students as it does not draw a clear line dividing transcription and spelling.

\section{Discussion}

The above-presented issues concerning the respelling of English words in Polish textbooks can serve as a springboard for further discussion on how and to what purpose the sound form should be represented in such contexts. Thus, the discussion will first juxtapose and compare two possible techniques of SFS - respelling and phonetic transcription; then it will analyse the possible extension of the aims of SFS; and finally, it will propose some solutions aimed at the improvement of SFS in L1 textbooks.

6 Both dental and alveolar are articulated with the tip of the tongue.

7 All the examples below will be given in brackets. 


\subsection{Respelling vs. phonetic transcription}

Both analysed textbooks adopted respelling as a technique of SFS. Thus, it is worth setting it against another possible solution which is the use of phonetic transcription (e.g. IPA). Each solution has its advantages which at the same time are the disadvantages of the other. And thus respelling:

- does not require learning an additional alphabet (both from teachers and students); this could be especially difficult with younger students (1-3 graders) who have recently been introduced to one alphabet, but even for older students introducing a phonetic alphabet, especially when it is not part of the curriculum for foreign languages, might be problematic and time-consuming;

- always results in a pronunciation; the fact that students (and teachers) are familiar with the symbols (letters of the alphabet) and (perhaps more importantly) the sounds they represent gives them instant access to the sound form of a word, even if the form is not very accurate (different from the original L2 form); phonetic alphabet, on the other hand, can be problematic in this respect, due to the fact that even if students succeed at getting familiar with the graphic form of the characters they might still struggle with the production of unfamiliar sounds (not present in their mother tongue) - learning them requires instruction and training;

- provides a domesticated version of the word; after all, in the context of L1 domestication is rather desired because it better serves the development of L1 better by enabling the introduction of new vocabulary into the language and strengthening the phonological awareness of L1.

When it comes to the use of phonetic transcription, the following advantages can be mentioned:

- it is accurate and consistent; the use of transcription ensures correct and consistent sound-symbol correspondence (which is not the case for respelling);

- it signals the discrepancy between sounds and letters better; the fact that sounds are represented with a different set of symbols than the native alphabet is a stronger signal that the two forms of language (written and spoken) are not in direct correspondence; compare the two graphical representations for Ethan [ifen] vs ['i:eən];

- it can be useful for learning other languages; of course, if introduced, a phonetic transcription (e.g. IPA) is widely used and could be a useful tool for learning foreign languages.

Even though the advantages of using phonetic transcription seem to counterbalance (if not outweigh) those of respelling only the latter technique appears to be a viable option in the circumstances of the schooling system. This is probably why the authors of textbooks choose it for the purpose of SFS. 


\subsection{Extended aims of respelling - missed opportunity}

As already mentioned, the main, or virtually, the only aim of respelling in the textbooks is to provide the sound pattern of words whose pronunciation could otherwise cause problems to students. However, the aims could be extended over simply providing a model of pronunciation and it could also be used as a pretext (opportunity) to develop students' linguistic awareness. This is especially important in the context of research which shows that there is a strong correlation between competence in L1 and learning foreign languages (Ellis 2015; Cook \& Singleton 2014) or new trends in glottodidactics which favour the concept of plurilingualism (Kotarba-Kańczugowska 2015). The plurilingual approach emphasizes contact with various languages, developing awareness of their existence, dependence and specificity. The student "builds up a communicative competence to which all knowledge and experience of language contributes and in which languages interrelate and interact" (CEFR: 4).

In this sense, the plurilingual approach does not apply only to foreign language classes. Explaining the pronunciation of foreign words in a mother tongue lesson is a perfect opportunity to develop pupils' language awareness of the similarities and differences between the L1 and foreign languages and to build on pupils' metalinguistic knowledge, to make generalizations referring to different languages, to establish connections between them and to formulate hypotheses about them.

In this context respelling could be used to develop students' linguistic awareness, e.g. with respect to (the list is by no means complete):

- the phonological systems of languages - not only words in different languages are different but what they are made of;

- the writing systems of languages - different languages make use of different alphabets;

- the discrepancy between these two systems - spelling and pronunciation can differ to a greater or lesser extent depending on the language (the problem of transparency of writing);

- the problem of domestication in foreign and borrowed words - e.g. the fact that it can take different forms: domestication of pronunciation but not writing (e.g. musical [mju'zikal]), domestication of both pronunciation and writing (e.g. keczup);

- the articulation of individual sounds - particular sounds of both L1 and L2 require particular motor movements of speech organs which are often, if not always involuntary and unconscious (even, or especially, for L1 sounds);

- the existence of various ways of transcription.

The above list shows the potential use that could be made of the respelling of foreign words in L1 textbooks and in this sense one can speak of a missed opportunity. As the analysis has shown, the ways of providing pronunciation information are very intuitive, often 
inconsistent or incomplete, which certainly does not foster conscious linguistic analysis on behalf of students. In addition, many analysed words lack the information on their origin which seems crucial both for the purposes of linguistic analysis and facilitating pronunciation, as the sound form of a given letter string depends on the language of the original, e.g. compare the pronunciation of the name Charles in Charles-Gerabed Atamian [szarlis garabid atamian] (TP4: 118) - a French painter of Armenian origin, Charles Schulz [czarls szulc] (MN4: 160) - an American comic book artist, and Charles Perrault [szarl pero] (MN4: 323) - a French fairy-tale writer.

\subsection{How to improve/clarify respelling in textbooks?}

Since it has already been suggested that the only viable form of SFS in the context of Polish educational system is the use of respelling one can think of the ways in which it can be improved to better serve the aims that were defined earlier. With respect to the first aim - enabling the pronunciation of foreign words - respelling could obviously be improved by ensuring consistency within a textbook. It has to be stressed that this one does not mean uniform rules of respelling as such, as it can be done for phonetic transcription, but consistent use of the solutions adopted in a given textbook throughout it. The consistency should concern both suprasegmental and (if possible) segmental level.

Another aspect in which respelling could be improved to help students pronounce foreign words is the introduction of stress marking. Without it the respelled word does not serve the purpose, as the pronunciation of words over one syllable long (especially those from languages with no fixed word stress, like English) becomes random.

With respect to the other aim - increasing students' linguistic awareness - respelling could be improved in two ways. Firstly, it should clearly distinguish between the two subcodes of language (written and spoken) to which aim it can use lexical as well typographical means. Lexical means include introducing SFS with words like wymawiaj 'pronounce' or czytaj 'read'. Typographical means concern the use of brackets, which is a commonly accepted convention for signalising sound forms, e.g. in phonetic transcription. Also, if the respelled forms are to distinguish between written and spoken forms they should definitely not use symbols which do not concern pronunciation, e.g. capital letters.

Moreover, the information on the language of origin should be provided, as this is closely linked to linguistic conclusions we can draw from a respelled form, e.g. a word can have an identical written form in two languages, but can be differently realized in pronunciation.

A technique which could help in realizing the two aims simultaneously (providing pronunciation and developing linguistic awareness) could be not to provide a sound form at all but to leave the job for students by providing a gapped place to be filled in by them. 
This would make students reflect on the sound form of the word and the accompanying language issues themselves. They would have to negotiate the possible sound form and discuss the aspects of language which apply in the particular context. And since respelling is a natural (and the only) tool students have at their disposal, textbooks could lead them in their thinking, allowing, however, a room for reflection and creativity, e.g. providing only the right number of gaps representing phonemes and the stress marking, as in the following example:

Lucky Luke wymawiaj [ _ - _ ‘ - $]$

The classroom methodology can have a major effect on how students learn, and this way of teaching could be an excellent opportunity for metalinguistic activity, which is currently assigned a special role in functional language education (Camps et al. 2000; Fontich 2014; Myhill et al. 2012). More cooperative interactions would help students to better explain their intuitions.

\section{Conclusion}

Both textbooks used respelling as the preferred technique for SFS. The choice seems justified taken into account the current circumstances of teaching L1 in Poland. Compared to phonetic transcription, it has one main advantage, namely, it comes naturally to students and teachers and does not require learning another alphabet. However, since it is based on native orthography, without real respect to the sound reality of speech, and, what is more, it is non-codified, its adaptation for the analysed textbooks raised several issues.

Provided that respelling is used in a systematic and consistent way throughout a textbook it can be a valuable tool for enabling students to pronounce the words which otherwise would be problematic. But not only that; the existence of foreign words in L1 textbooks could also be treated as an opportunity to increase students' awareness pertaining to many aspects of linguistic reality balancing between speech and writing. This opportunity does not seem to be fully embraced; however, a provision has to be made. The analysis dealt with the content of textbooks, not with the content of classes (where the textbooks are actually used). Obviously, an experienced teacher can use a textbook for purposes that were not devised by its authors or even if it contains some mistakes. And conversely, even the best textbook will not be much of help for a badly prepared teacher. In this context, the phrase "unseized opportunity" from the title of the article should perhaps be followed by a question mark. 


\section{References}

Awramiuk, E. 2018. Fonetyka w podręcznikach do nauki języka ojczystego [Phonetics in L1 textbooks]. In: E. Awramiuk \& A. Rozumko (eds.), Z problematyki kształcenia językowego, vol. VII, 167-185. Białystok: Wydawnictwo Uniwersytetu w Białymstoku.

Bartmiński, J. 2014. Czym w podstawie programowej jest świadomość językowa [What language awareness means in the core curriculum]. In: K. Biedrzycki, W. Bobiński, A. Janus-Sitarz \& R. Przybylska (eds.), Polonistyka dziś - ksztatcenie dla jutra, vol. 3, 37-49. Kraków: Universitas.

Camps, A., Guasch, O., Milian, M., \& Ribas, T. 2000. Metalinguistic activity: The link between writing and learning to write. In: A. Camps \& M. Milian (eds.), Metalinguistic Activity in Learning to Write, 103-124. Amsterdam, The Netherlands: Amsterdam University Press.

CC 2008: Podstawa programowa ksztatcenia ogólnego dla szkót podstawowych [General education core curriculum for primary schools]. Appendix No. 2 to the Regulation of the Ministry of Science and Higher Education of 23 December 2008. Journal of Laws of 2009, No. 4, Item 17.

CC 2014: Podstawa programowa ksztatcenia ogólnego dla szkót podstawowych [General education core curriculum for primary schools]. Appendix No. 2 to the Regulation of the Ministry of Science and Higher Education of 30 May 2014. Journal of Laws of 2014, No. 0, Item 803.

CC 2017: Podstawa programowa ksztatcenia ogólnego dla szkót podstawowych [General education core curriculum for primary schools]. Appendix No. 2 to the Regulation of the Ministry of Science and Higher Education of 14 February 2017. Journal of Laws of 2017, Item 356.

CEFR: Common European Framework of Reference for Languages: Learning, Teaching, Assessment. Council of Europe 2011.

Cook, V. \& Singleton, D. 2014. Key Topics in Second Language Acquisition. Bristol, Buffalo, Toronto: Multilingual Matters.

Ellis, R. 2015. Understanding Second Language Acquisition (2 ${ }^{\text {nd }}$ edition). Oxford: Oxford University Press.

Fontich, X. 2014. Grammar and language reflection at school: Checking out the whats and the hows of grammar instruction. In: T. Ribas, X. Fontich \& O. Guasch (eds.), Grammar at School: Research on Metalinguistic Activity in Language Education, 255-284. Brussels: Peter Lang.

Furtak, Ł. 2015. In defense of the usefulness of a Polish-based respelling phonetic transcription system in the elementary to lower-intermediate EFL classroom. In: E. Waniek-Klimczak \& M. Pawlak (eds.), Teaching and Researching the Pronunciation of English: Studies in honour of Wtodzimierz Sobkowiak, 119-135. Cham: Springer. 
Heselwood, B. 2013. Phonetic Transcription in Theory and Practice. Edinburgh: Edinburgh University Press.

Kietlińska, A. \& Awramiuk, E. 2016. Szkolny polonista w dobie powszechnej znajomości języków obcych [The Polish language teacher in school in the era of widespread knowledge of foreign languages]. In: E. Jaskółowa, D. Krzyżyk, B. Niesporek-Szamburska, \& M. Wójcik-Dudek (eds.), Edukacja polonistyczna jako zobowiazanie. Powszechność i elitarność polonistyki, vol. 1, 557-571. Katowice: Wydawnictwo Uniwersytetu Śląskiego. Kotarba-Kańczugowska, M. 2015. Edukacja otwarta na języki. Rożnojęzyczność w teorii $i$ praktyce [Education open to languages. Plurilingualism in theory and practice]. Kraków: Oficyna Wydawnicza „Impuls”.

Kowalikowa, J. 2014. Od słowa do zdania, od zdania do tekstu - od tekstu do zdania, od zdania do słowa [From word to sentence, from sentence do text - from text to sentence, from sentence to word]. In: A. Janus-Sitarz \& E. Nowak (eds.), Szkolna polonistyka zanurzona w języku, 17-43. Kraków: Universitas.

Myhill, D.A., Jones, S.M., Lines, H. \& Watson, A. 2012. Re-thinking grammar: the impact of embedded grammar teaching on students' writing and students' metalinguistic understanding. Research Papers in Education 27(2): 139-166.

National Early Literacy Panel 2008: Developing Early Literacy: Report of the National Early Literacy Panel. Washington. lincs.ed.gov/publications/pdf/NELPReport@9.pdf.

Nupponen, A.-M., Jeskanen, S. \& Rättyä, K. 2019. Finnish student language teachers reflecting on linguistic concepts related to sentence structures: Students recognising linguistic concepts in L1 and L2 textbooks. L1-Educational Studies in Language and Literature 19: 1-25. https://doi.org/10.17239/L1ESLL-2019.19.02.04

NSPP: Nowy stownik poprawnej polszczyzny [A New Dictionary of Correct Polish], ed. A. Markowski, Warszawa 2000.

Svalberg, A. M. 2012. Language Awareness in Language Learning and Teaching: A Research Agenda. Language Teaching 45(3): 376-388.

\section{Analysed textbooks}

MN4: A. Łuczak, A. Murdzek, K. Krzemieniewska-Kleban, Między nami. Język polski 4, wyd. drugie, Gdańsk 2018, Gdańskie Wydawnictwo Oświatowe.

MN5: A. Łuczak, A. Murdzek, Między nami. Język polski 5, Gdańsk 2018, Gdańskie Wydawnictwo Oświatowe.

MN6: A. Łuczak, A. Murdzek, Między nami. Język polski 6, Gdańsk 2014, Gdańskie Wydawnictwo Oświatowe.

TP4: A. Klimowicz, Teraz polski! Podręcznik do ksztatcenia literackiego, kulturowego i jezzykowego dla klasy czwartej szkoty podstawowej, Warszawa 2013, wyd. drugie, Nowa Era. 
TP5: A. Klimowicz, Teraz polski! Podręcznik do ksztatcenia literackiego, kulturowego i językowego dla klasy piątej szkoty podstawowej, Warszawa 2016, Nowa Era.

TP6: A. Klimowicz, Teraz polski! Podręcznik do kształcenia literackiego, kulturowego i językowego dla klasy szóstej szkoty podstawowej, Warszawa 2017, Nowa Era.

$$
* * *
$$

Elżbieta Awramiuk is a professor of linguistics at the University of Białystok. Her research concentrates on knowledge about language in education, as well as phonology and spelling of the contemporary Polish language. She is a founding member of ARLE (International Association for Research in L1 Education) and she is engaged in the Special Interest Group Research Educational Linguistics (SIG EduLing). She has participated in several research projects focused on the early literacy development and assessment, and linguistic aspects of learning to read and write.

Michal Citko is a doctoral student at the University of Białystok. He is interested in the relationship between perception and production of speech in first and second language acquisition. His doctoral thesis will concern articulatory awareness in learning Polish as a foreign language. He is a foreign language teacher of English and Polish. 